\title{
Effectiveness of the GAEC cross-compliance standard protection of permanent pasture in relation to grazing and pasture conservation management in marginal mountain areas
}

\author{
Cristina Potenza, Vincenzo Fedele \\ Agricultural Research Council (CRA), Unit of research of Extensive Animal Production, of Bella, \\ Muro Lucano, Italy
}

\begin{abstract}
Population decline, that took place in mountain areas of Italy since the 1950s, determined deep changes in both land use and landscape ecology. The maintenance of natural pastures, within the framework of a control program (Italian GAEC standard 4.1a of cross compliance), represents a relevant action for a correct ecosystem management in order to preserve the floristic richness and, as a consequence, habitat biodiversity; it can also transform the pastures into a permanent feed resource not only for domestic livestock, but also for wild fauna.

When the grazing activity is managed with rational criteria can be vital to preserve biodiversity, allowing the maintenance of those habitats in danger of disappearance. The aim of grazing management should be the preservation of habitat and biodiversity. The specific objective of the rule $4.1 \mathrm{a}$ of cross-compliance is to ensure a minimum level of maintenance and to avoid the decay of habitats through the prohibition to reduce the surface destined to permanent pastures.
\end{abstract}

\section{Introduction}

Since the half of the last century the depopulation of mountain areas has determined deep changes in the usage of the Italian territo-

\author{
Correspondence: Cristina Potenza, Agricultural Research Council (CRA), \\ Unit of research of Extensive Animal Production, via Appia, Bella Scalo, \\ 85054 Muro Lucano (PZ), Italy. \\ Tel. +39.0976.72915 - Fax: +39.0976 .79930 . \\ E-mail: cristina.potenza@unibas.it \\ Key words: mountain areas, pastures, grazing resources. \\ Received for publication: 25 March 2011. \\ Accepted for publication: 19 May 2011. \\ CC Copyright C. Potenza and V. Fedele, 2011 \\ Under no circumstances figures can be used without prior written consent \\ of the copyright owner. \\ Licensee PAGEPress, Italy \\ Italian Journal of Agronomy 2011; 6(s1):e11 \\ doi:10.4081/ija.2011.6.s1.e11
}

This work is licensed under a Creative Commons Attribution NonCommercial 3.0 License (CC BY-NC 3.0). ry and landscape. The reasons of the abandonment of agricultural lands and mountain pastures have to be investigated into the socioeconomic changes, which affected Italy from the 1950s (Genghini, 2007). One of the most striking consequences, due to the abandonment, is the reduction of the area occupied by open habitats, above all grassland and pasture, in marginal areas (Lombardi et al., 2001).

The consequence of this progressive closing (Figure 1) is the remarkable reduction of biodiversity in these territories, in particular as regards some vegetable species. The great ecological value of natural pasture, including ecotone ranges (i.e. passing zone between an arboreal covered area and an open area), is shown with a significant increase in species along these transition ranges (Argenti et al., 2002).

During the secondary succession process that follows the abandonment of agricultural, woodland and grazing practices on lands, the most ecologically specialized species are gradually replaced by more competitive ones. All these factors cause a huge decrease of the vegetable biodiversity and a fast disappearance of herbaceous associations, endemisms and geophyte flowering plants; thus, in general, a floristic and vegetation simplification takes place in dismissed grazing areas (Staglianò et al., 2003).

The maintenance of natural pastures through a control programme represents, so far, an important action for a correct management of the ecosystem, in order to preserve the floristic richness and, as a consequence, the biodiversity in the habitat, transforming the pastures into a permanent feed resource not only for the livestock, but also for wild animals.

Anyway, there is neither continuous monitoring on the evolution of flora for natural forage resources, nor exact and accurate measurements of the causes of these changes. In the past, investigations were carried out using various methodologies with different aims and, for this reason, difficult to be compared nowadays. Thus, it is almost impossible to carry out some controls with a suitable time gap, in order to fully estimate the evolution of vegetation in relation to the changes in the grazing zootechny.

It is necessary to fill this gap, arranging a suitable plan of standard survey based upon a common methodology and a series of parameters which are considered important for the control of evolution of resource, during the time, and for the evaluation of the consequences in the management, in order to improve it, where necessary. The monitoring actions of grazing resources ought consider not only the quantitative parameters that are usually examined (pasture extension, productive capacity, seasonal distribution of the production, indexes linked to stocking rate capacity, e.g. the pastoral value, etc.), but also a series of variables regarding other extremely important functions which can be performed by pastures, such as landscaping, naturalistic and socio-economic ones. The knowledge of grazing resources under 
all these aspects allows to completely evaluate them and to functionally implement some sustainable management guidelines for these fundamental resources, in order to preserve the habitats and biodiversity.

As previously told, grassland and natural pastures are extremely sensitive to usage variations, since they are often formations of secondary origin, created by man in place of forests which, on the contrary, would result to be the climax formations of reference. This arises the peculiarity of grassland and grazing resources which, if not well managed (or not managed at all, as it happens in many areas in Italy), could experience surface contractions, for the return of shrubs, foreshadowing the territory regain by the woods and qualitative decay for the appearance of a series of extremely variable vegetable associations, depending on pedoclimatic conditions, such as closed, dry or mesophile, perennial Nardus grasslands occupying siliceous soils in Atlantic or sub-Atlantic or boreal lowland, hill and mountain regions (Habitat 6230 Directive 92/43/EEC), dry to semi-dry calcareous grasslands of the FestucoBrometea (Habitat 6210 Directive 92/43/EEC), the most different shrub formations.

In particular, the consequences of wrong pasture usage can be summarized as follows: i) decrease in productivity and qualitative decay, which can compromise, for the future, the recovery of degraded resources; ii) relevant increase of necromassa, composed by not used vegetable material, which reduces the sunlight penetration in the lower layers of the turfgrass; iii) decrease of biodiversity, with the banalization of composition and development of herbaceous coenoses frequently characterized by a restricted number of species; iv) return, during the mid-long term period, to closed forest formations, which can cause the decrease of landscape value of the area.

Obviously, the evolution towards these kinds of degraded resources is almost always to be linked either to the reduced grazing activity or to its disappearance. The conservative management of natural resources requests the planning of stocking rates and systems of grazing management compatible with the availability and quality of forage resources. It is also important to consider the actual trend, which shows a progressive disappearance of the zootechnical population from natural grazing areas. If farmers and shepherds, instead of being supported and enhanced, also through financial resources, will continue to be stopped by a lot of bonds regulating the grazing in public lands, a revival of zootechnical activity in hilly and mountainous areas appears difficult.

When the grazing activity is managed with rational criteria (Figure 2 ), it is able to play an important role in the preservation of biodiversity, allowing the maintenance of those endangered habitats (Bornard $e t$ al., 1996). For this reason, it is essential to establish grazing pressures compatible with the maintenance of biocoenosis, to evaluate the frequency and severity of grazing and choosing the right kind of grazing animal, in order to preserve not only the natural grazing surfaces, but also the quality of pastures themselves and the numerous functions they play.

\section{Natural pastures in Italy}

In Italy, natural pastures, formed by evolution and following stabilization of spontaneous vegetation, are still a widely spread forage resource, having a huge value as for productive aims by zootechnical farms, for the environmental preservation of marginal areas and for the nutraceutical quality of animal productions. The characteristics of these herbage resources are variable, above all for the extreme diversity of peninsular landscapes and the remarkable reactivity of these vegetation and the various agroecological aspects characterizing the areas in which they are present.

Moreover, grassland and pastures are undoubtedly fundamental components, with roles and functions, which are well defined and often irreplaceable. This is due to the huge extension of the surface, their ubiquitous presence, the climax formation role at those altitudes to which the wood cannot achieve and the high number of floristic entities and animal species.

Among the main distinctive elements of permanent forage resources, it is particularly important the role of the wide richness in flora and fauna populating grassland and pastures and the remarkable variability linked to the fast climate change which make these resources extremely important for the preservation, in situ, of biodiversity at all its levels: genetic, site-specific and eco-systemic. In particular, the contact areas between grazing and woods show the highest floristic richness and an overlapping of heliophilous species of open areas and sciophilous species of underwood (Argenti et al., 2000).

The areas dominated by herbaceous vegetation represent important pieces of the landscape and, together with other kinds of soil use, give heterogeneity and variability to the environment, making it less monotonous thanks to the alternation of open-spaces and wooden, closed and less accessible areas, above all at low altitude. This wealth of environments is a variability of habitat for wildlifeand for spontaneous flora, which further increases the biological diversity of the territory

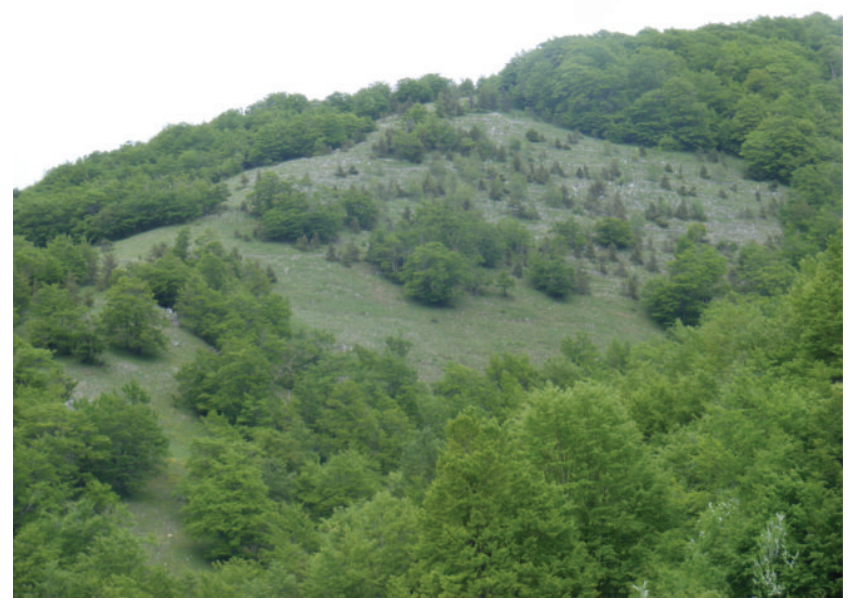

Figure 1. Reduction of the area occupied by open habitats: progressive closing (M. Arioso-Appennino Lucano, PZ, Italy. Courtesy of C. Potenza).

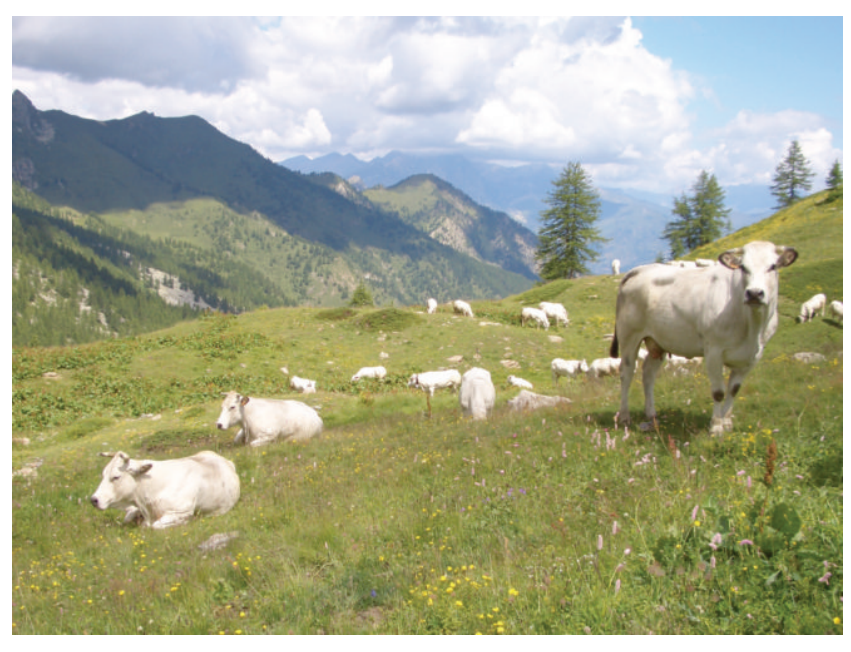

Figure 2. The maintenance of natural pastures with rational criteria (Alpe Valanghe, Val Maira, CN, Italy. Courtesy of M. Verona). 
(Sabatini et al., 2001). During the last decades this use of land resources has greatly decreased because of the new socio-economic conditions of agriculture and the changes in the management and feeding criteria of zootechnical farm (Ziliotto et al., 1992).

The main cause of the decrease of grazing surface in Italy can be traced back to the abandon of crops and pastures since the $50 \mathrm{~s}$ of the last century, which brought to deep transformations in the use of the territory. The colonization of these areas by the spontaneous vegetation has taken place through different mechanisms and times, which caused a specific composition of post-crop formation. The latter was diversified depending on the stational conditions, the previous usage of the soil and the structure of the agroforestry landscape (Pelleri and Sulli, 2000; Piussi, 2002).

As regards the Italian situation, the Alps and the Prealps are characterized by a direct colonization of arboreal species (Salbitano, 1988; Aceto et al., 2000; Pelleri and Fontana, 2003), while in the Apennines and in the Mediterranean area, a gradual and slower dynamics, often characterized by an intermediate phase with shrubs, is generally spread (Ubaldi, 1976; Canullo, 1993; Petrocelli et al., 2003; Pelleri et al., 2003). Also for those cases of simple decrease of grazing activities, recolonization phenomena by shrub and arboreal species are sparked off; their evolution brings to the re-establishment of wood which constitute the full-grown stages of the vegetation series (Argenti et al., 2002; Tappeiner et al., 1993). Consequently, beyond the loss of surface, there is also the qualitative decay of the turfgrass, because of the disappearance of species, not appetite by animals, which can become prevailing. The latter, being less used by the animals, can give raise to disparity between phytomass availability and intake and, at the same time, also to the loss of the genetic heritage of typical herbaceous species (Delpech and Vertes, 1992; Nösberger and Kessler, 1997).

\section{Rule of Italian GAEC standard 4.1a of cross compliance}

The specific objective of the rule 4.1a of cross compliance is to ensure a minimum level of maintenance and avoid the decay of habitats through the prohibition to reduce the surface destined to permanent pastures.

Differently from what happened for forests, there has not been a similar flourishing of applicative and methodological studies for forage resources, i.e. grassland and pastures, for informative aims. As a matter of fact, in the view of numerous botanical analyses carried out on Italian semi-natural grasslands and scrubland facies on calcareous substrates (Festuco-Brometalia), important orchid sites (Figure 3) and grazing areas, which led to a good floristic knowledge of different environments, there are few studies about management, generally limited to the farm.

Some important synthesis works have regarded the main agronomic aspects of pastures of the whole Italian territory; one of them (Ziliotto et al., 1992) in particular, presented the phyto-pastoral characterization with the identification of the main grazing types; other studies discussed about the dynamics and the seasonal distribution of their production (Talamucci et al., 1987; Sarno et al., 1989; Cavallero et al., 1992). In all studies, because of their various aims, it has not been possible either to perform more detailed analyses or to build a monitoring network for the evaluation of the turfgrass evolution and his parameters during the time.

It results to be of primary importance to fill in the informative gap related to the meadow- grazing sector, achieving complete inventories not only based upon the knowledge of the resource dimension (surfaces, kinds of information, productivity, quali-quantitative indexes), but also on the ecological (biodiversity, grade of naturalness, fluxes of

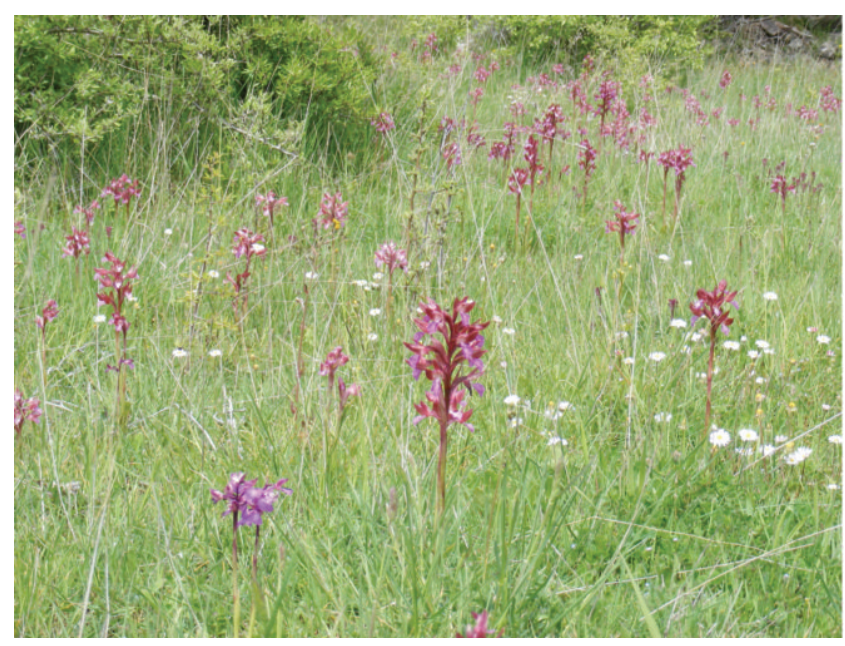

Figure 3. Habitat $6210^{*}$ Festuco-Brometalia important orchid sites (M. Serranetta, Appennino Lucano, PZ, Italy. Courtesy of C. Potenza).

nutritional elements), economic (linked to local, biological and niche products and to services) and social (cultural and environmental goods, landscape, entertaining, tourist and sport activities) characteristics, as a fundamental base to plan and define sustainable and eco-compatible guidelines (Sabatini et al., 2001).

\section{Conclusions}

As regards the grazing resources, the main cares should concern above all their management. They are often considered secondary resources if measured with the criterion of the cultivated foraging, but definitively primary if considered in the context of extensive grazing systems. Being resources of anthropic origin, and thus in delicate balance with the usage conditions, they need a careful management, which cannot be set up into a simple preservation.

With this idea, it could be possible to verify if the grazing eco-systems are in a balance (or climax) state and if the aim of preservation is to keep this condition. However, in most cases they are herbaceous coenoses far from a balance condition. For this reason, the lack of interventions could bring to the worsening or even to the disappearance of the resources themselves. Consequently, the grazing resources appear very delicate matter; it expresses itself into the proposal and accomplishment of a wise management, in order to avoid the decay and impoverishment of a kind of resource that, in Italy, takes an alimentary relevance not at all negligible.

The aim of the grazing management should be the preservation of biodiversity, through a usage able to reduce the floristic simplification and banalization. This result can be obtained with a minimal management of the livestock. An optimal management would request some efforts, engagement and organization not workable at the moment and characterized by light stocking rates, maybe alternating different herbivorous within the years, able to create a mosaic of microenvironments and to keep high the number of species and genotypes. Minimal usages can preserve natural herbaceous resources at a good level, better than the simple maintenance, both on a productive point of view, with a light increase in the offered phytomass and pastoral value, and ecological, with increase in the species characterizing the turfgrass and decrease of the necromassa and loss of soil due to the erosion.

The management can be realized according to different procedures: 
i) through the control of wildlife, the knowledge of the social organization of the species and the habitat usage; ii) through the introduction of user animals coming from other areas (neighbouring areas, within an integrated system); iii) using service flock coming from far areas.

It is basic that the preservation of wide-ranging grazing resources, with all those kinds of interventions previously showed, implies as indirect consequence the preservation of resources also available by wild animals. The maintenance must be considered under the double sense of the grazing resource preservation from a quantitative, but also qualitative, point of view. The latter aspect can also be subjected to degrading variations faster than the retention of the resource extension. The grazing resources considered meaningless for domestic animals, because of either small extension or presence of other resources such as the forestry, and so not really economically exploitable, are some resources of primary importance for wild species: their maintenance ought be promoted by all means, also if the usual domestic user are absent (by reaping and hedge trimming through sylvicultural interventions).

From this perspective, it is important to enhance the transition stripes between pasture and wood, where wild animals, thanks to the wide variability of their trophic spectrum, can draw not only from herbaceous resources but also from wood ones, through nibbling young tops and leaves. The pasture characterized by a modest shrub density, which does not significantly interfere with the quali-quantitative aspects of the herbaceous vegetation, should be adequately controlled and preserved because forests are a precious reserve of alimentary availability, in periods of herbage scarceness, and a repair from thermal excesses. A particular attention must be also addressed to wild fruit species because of their importance in autumn, through the supply of very appetizing fruits not only for wild animals, but also for ruminants. Finally, the presence of animals in the shrubs and wood frequently represents a powerful means to avoid the trigger and the spread of fires. The grazing animals, either domestic or wild, avoid the narcotisation of herbaceous vegetation and clean the wood from a lot of shrub vegetation, often creating real fire-fighting barriers.

\section{References}

Aceto P., Pividori M., Siniscalco C. 2000. Dinamica evolutiva di popolamenti forestali di neoformazione nel piano montano. Monti e Boschi 1:4-12.

Argenti G., Bianchetto E., Sabatini S., Staglianò N., Talamucci P. 2002. Indicazioni operative per la gestione delle risorse pastorali nei Parchi Nazionali. In: Linee guida per la gestione sostenibile delle risorse forestali e pastorali nei Parchi Nazionali. Ministero dell'Ambiente e della tutela del territorio, Servizio Conservazione della Natura, Accademia Italiana di Scienze Forestali, Firenze, Italy, pp 155-203.

Argenti G., Sabatini S., Staglianò N., Talamucci P. 2000. Vegetazione prato-pascoliva infraforestale e biodiversità di un'area alpina orientale. Atti del $2^{\circ}$ Congresso SISEF Applicazioni e prospettive per la ricerca forestale italiana, Bologna, Italy, pp 267-272.

Bornard A., Cozic F., Brau-Nogue C. 1996. Diversitè specifique des vegetations en alpage: influence des conditions ecologiques et des pratiques. Ecologie 27:103-115.

Canullo R. 1993. Lo studio popolazionistico degli arbusteti nelle successioni secondarie: concezioni, esempi ed ipotesi di lavoro. Ann. Bot. 51:379-394.

Cavallero A., Talamucci P., Grignani C., Reyneri A. 1992. Caratteriz- zazione della dinamica produttiva di pascoli naturali italiani. Riv. Agron. 26:325-343.

Delpech R., Vertes F. 1992. Effets de l'extensification sur la flore et la végétation prairiales. In: L'extensification en production fourragère. Compte-rendues Journées 1992 de l'AFPF, pp 114-115.

Genghini M. 2007. Territori di collina e di montagna e politiche agricole: effetti ed opportunità per la fauna selvatica. In: M. Lucifero and M. Genghini (eds.) Valorizzazione agro-forestale e faunistica dei territori collinari e montani, Istituto Nazionale Fauna Selvatica, Ministero delle Politiche agricole, alimentari e forestali, Sterna Ed., Toscanella di Dozza (B0), Italy, pp 13-42.

Lombardi G., Reyneri A., Cavallero A., Argenti G., Sabatini S., Staglianò N., Talamucci P. 2001. La gestione conservativa delle superfici pastorali dell'arco alpino. In:E. Piano, R. Paletti and M. Bassingana (eds.) Contributi alla conoscenza scientifica. P.F. MiPAAF, Gestione delle risorse prato-pascolive alpine, Aosta, IT, pp 7-15.

Nösberger J., Kessler W. 1997. Utilisation of grassland forbiodiversity. In: Management for grassland biodiversity. pp 33-42 in Proc. Int. Occasional Symp. European Grassland Federation, Warsaw-Łomża, Poland.

Pelleri F., Fontana S. 2003. Primi interventi selvicolturali per la valorizzazione degli acero-frassineti di neoformazione realizzati nella Comunità Montana Agno-Chiampo. Sherwood. 91:7-14.

Pelleri F., Milandri M., Ferretti F. 2003. L'avanzamento del bosco nell'Appennino Tosco-Romagnolo: il caso di Premilcuore. Proc. 4th Congr. Nazionale SISEF Meridiani Foreste, Rifreddo (PZ), Italy, pp 135-140.

Pelleri F., Sulli M. 2000. Campi abbandonati e avanzamento del bosco. Un caso di studio nelle Prealpi lombarde (Comune di Brinzio, Provincia di Varese). Ann. Ist. Sper. Selv. 28:89-125.

Petrocelli F., Bianchi L., Paci M. 2003. Gli oliveti abbandonati delle colline fiorentine: evoluzione della vegetazione e implicazioni paesaggistiche. Monti e Boschi 5:41-46.

Piussi P. 2002. Rimboschimenti spontanei ed evoluzioni post-coltura. Monti e Boschi 53:31-37.

Sabatini S., Argenti G., Bianchetto E, Staglianò N. 2001. Il monitoraggio delle risorse prative e pascolive per la definizione di idonee linee di gestione pastorale sostenibile. Comunicazione di Ricerca dell'ISAFA 2001/2, pp 93-100.

Salbitano F. 1988. I boschi di neoformazione in ambiente prealpino. Il caso di Taipana (Prealpi Giulie). Monti e Boschi 6:17-24.

Sarno S., Talamucci P., Cavallero A. Stringi L. Eds. 1989. Distribuzione della produzione dei pascoli in ambienti marginali italiani. Guida alla valutazione della produttività. Progetto finalizzato CNR-IPRA Aree marginali. Arti Grafiche Ed., Palermo, Italy, pp 7-17.

Staglianò N., Argenti G., Albertosi A., Bianchetto E. Sabatini S. 2003. La gestione delle risorse pastorali e le relazioni con gli ambienti forestali. pp 99-108 in Atti Convegno Selvicoltura e Paesaggi Forestali in Appennino, Santuario della Verna, AR, Italy.

Talamucci P., Sarno R., Cavallero A. 1987. I sistemi foraggeri. pp 133177 in: CNR IPRA (ed.) I sistemi agricoli marginali. Rapporto intermedio. FARAP Press, Bologna, Italy.

Tappeiner U., Cernusca A.1993. Rapporti dinamici fra pascoli abbandonati e bosco. Risultati delle ricerche svolte nell'ambito del programma austriaco MaB e del progetto CEE-STEP-INTEGRALP. ISAFA Comunicazioni di ricerca 1:67-80.

Ubaldi D. 1976. La vegetazione dei campi abbandonati delle Marche e in Romagna: aggruppamenti erbacei e arbustivi. Not. Fitosoc. 12:49-56.

Ziliotto U., Scotton M., Stringi L. 1992. Caratterizzazione floristica dei pascoli italiani. Riv. Agron. 26:295-324. 